\title{
Predator-induced defence in a dinoflagellate generates benefits without direct costs
}

\author{
Ryderheim, Fredrik; Selander, Erik; Kiørboe, Thomas
}

Published in:

ISME Journal

Link to article, DOI:

10.1038/s41396-021-00908-y

Publication date:

2021

Document Version

Peer reviewed version

Link back to DTU Orbit

Citation (APA):

Ryderheim, F., Selander, E., \& Kiørboe, T. (2021). Predator-induced defence in a dinoflagellate generates benefits without direct costs. ISME Journal, 2107-2116. https://doi.org/10.1038/s41396-021-00908-y

\section{General rights}

Copyright and moral rights for the publications made accessible in the public portal are retained by the authors and/or other copyright owners and it is a condition of accessing publications that users recognise and abide by the legal requirements associated with these rights.

- Users may download and print one copy of any publication from the public portal for the purpose of private study or research.

- You may not further distribute the material or use it for any profit-making activity or commercial gain

- You may freely distribute the URL identifying the publication in the public portal

If you believe that this document breaches copyright please contact us providing details, and we will remove access to the work immediately and investigate your claim 
1 Predator-induced defence in a dinoflagellate generates benefits without direct costs

2 Fredrik Ryderheim $^{1 *}$, Erik Selander ${ }^{2}$ and Thomas Kiørboe ${ }^{1}$

1) Centre for Ocean Life, DTU Aqua, Technical University of Denmark, Kemitorvet, 2800 Kgs. Lyngby, Denmark

2) University of Gothenburg, Department of Marine Sciences, Carl Skottsbergs gata, 41319 Göteborg, Sweden.

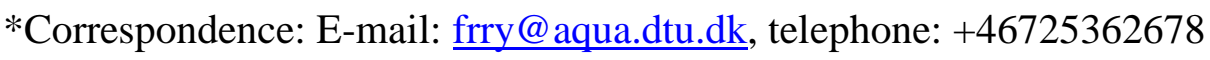

Running head: Defensive benefits without direct costs

Keywords: trade-offs, dinoflagellate, Alexandrium minutum, toxin production, copepodamides, defence mechanisms

\section{Conflict of interest}

4 We declare we have no conflict of interest.

6 This paper has been published:

7 Ryderheim, F., E. Selander, and T. Kiørboe. 2021. Predator-induced defence in a

8 dinoflagellate generates benefits without direct costs. ISME J 15: 2107-2116.

9 doi:10.1038/s41396-021-00908-y

10

11 This is a post-peer-review, pre-copyedit version of the article published in The ISME Journal

12 by Springer Nature. The final authenticated version is available online at:

13 https://doi.org/10.1038/s41396-021-00908-y. 

Abstract
14 Inducible defences in phytoplankton are often assumed to come at a cost to the organism, but trade-offs have proven hard to establish experimentally. A reason for this may be that some trade-off costs only become evident under resource-limiting conditions. To explore the effect
17 of nutrient limitation on trade-offs in toxin-producing dinoflagellates, we induced toxin production in Alexandrium minutum by chemical cues from copepods under different levels
19 of nitrogen limitation. The effects were both nitrogen- and grazer-concentration dependent. Induced cells had higher cellular toxin content and a larger fraction of the cells was rejected by a copepod, demonstrating the clear benefits of toxin production. Induced cells also had a higher carbon and nitrogen content, despite an up to $25 \%$ reduction in cell size. Unexpectedly, induced cells seemed to grow faster than controls, likely owing to a higher specific nutrient affinity due to reduced size. We thus found no clear trade-offs, rather the opposite. However, indirect ecological costs that do not manifest under laboratory conditions may be important. Inducing appropriate defence traits in response to threat-specific warning signals may also prevent larger cumulative costs from expressing several defensive traits simultaneously. 


\section{Introduction}

Dinoflagellates of the genus Alexandrium produce neurotoxic alkaloids collectively known as paralytic shellfish toxins (PST). The toxins are efficient sodium-channel blockers and among the most potent toxins known [1]. The intracellular toxin content is up-regulated in response to the level of threat from zooplankton grazers [2] and, while debated, toxicity as a defence mechanism against grazers is the favoured explanation for the evolution of algal toxins [3-6].

Studies dedicated to defence mechanisms in phytoplankton often focus on the benefits of the defence, but rarely establish potential costs [7]. So far, experimental assessments have suggested toxin production trade-offs to be insignificant. The growth rate of toxic and nontoxic strains of the same species, or grazer-induced versus non-induced cells with very different toxin contents appear to be identical $[2,8,9]$. Blossom et al. [10] compared several species and strains of Alexandrium spp. and did not find any correlation between growth rate and toxin production under light-replete conditions, and even a positive correlation under limiting light. Brown \& Kubanek [11] recently demonstrated a negative relation between toxin content and growth rate in Alexandrium minutum exposed to lysed cells of various other species of dinoflagellates, thus suggesting a trade-off. However, the correlation may also result from allelochemical substances in the lysed cells reducing growth [12]. Many dinoflagellates produce such dissolved allelochemicals that reduce the growth rate of other cells [13] and when growth is reduced cells commonly become more toxic [14]. Significant costs of predator-induced toxin production have so far only been convincingly demonstrated in diatoms that produce domoic acid, but here the benefits of the toxins are still debated [15]. However, ecological theory predicts associated costs; otherwise, non-defended species or strains would be outcompeted and only defended species would persist. Also, toxin production is inducible; i.e., it is up-regulated in the presence of grazers cues, as seen in Alexandrium spp. dinoflagellates $[2,16,17]$ and some toxic strains of the diatom Pseudo- 
nitzschia $[15,18]$. According to optimal defence theory, inducible defences are favoured when predation risks vary in time and defence costs are significant $[19,20]$. While these costs have likely been reduced through evolution, the wide variety of inducible defences found in both marine and terrestrial organisms suggests the presence of influential trade-offs to any beneficial defensive trait [21-24].

The failure of experiments to demonstrate costs may be due to the fact that experimental assessments have often been done under resource-replete conditions, while costs may be more significant when resources are limited [7, 20, 25-27]. The PST molecules are high in nitrogen with $\mathrm{N}: \mathrm{C}$ ratio 4.6 times higher than average phytoplankton materials [28].

Numerous studies have shown cell toxin content to be low in nitrogen-depleted cells $[29,30]$ even when exposed to a grazer threat [9]. Trade-off costs may be trivial when nutrients and light are plentiful, but when available nitrogen is limiting and grazer biomass high, a fitnessoptimization resource-allocation model predicts a significant growth penalty to toxin production [31]. Nitrogen limitation in temperate shelf regions generally occurs during the summer months $[32,33]$, and coincidentally it is during these months that defence is most needed due to peaking copepod biomass [33, 34].

Here, we quantify the benefits and costs of toxin production in Alexandrium minutum under different degrees of nitrogen limitation using both a chemostat approach and classical batch experiments. The compounds from zooplankton that trigger toxin production are known [35], and we use them for precise manipulation of toxin production without confounding effects of grazing on fitness estimates. The efficiency of the defence is estimated by video recording the response of copepods to induced and non-induced cells. Following the predictions of the model of Chakraborty et al. [31], we hypothesize that the costs of increased toxicity of induced cells will be highest at intermediate nitrogen limitation, and that cells grown in excess of nitrogen will reap full benefit while paying negligible costs. 
Alexandrium minutum strain GUMACC 83 were grown in B1 medium [36] at salinity 26, 18

${ }^{\circ} \mathrm{C}$, and an irradiance of $c a .150 \mu \mathrm{mol}$ photons $\mathrm{m}^{-2} \mathrm{~s}^{-1}$ on a 12:12 light:dark cycle. To reduce carry-over of nitrogen from the stock culture we diluted cells in $\mathrm{B} 1$ with reduced $\mathrm{NO}_{3}{ }^{-}(80$ $\mu \mathrm{M})$ for two weeks prior to inoculation and used cells that were close to the end of the exponential phase.

Batch-culture experiment

Six replicate batch cultures of $A$. minutum were initiated at $c a .200$ cells $\mathrm{mL}^{-1}$ in $2 \mathrm{~L}$ blue-cap glass flasks exposed to $c a .150 \mu \mathrm{mol}$ photons $\mathrm{m}^{-2} \mathrm{~s}^{-1}$ on a 12:12 light:dark cycle and constant temperature of $18{ }^{\circ} \mathrm{C}$. We used modified $\mathrm{B} 1$ medium with reduced nitrogen concentration (60 $\mu \mathrm{M} \mathrm{NO}_{3}{ }^{-}$) to make sure that the cells eventually would be limited by nitrogen rather than other resources. The cultures were gently bubbled to avoid high $\mathrm{pH}$ limiting growth. $\mathrm{pH}$ was monitored using a PHM220 Lab pH meter (Radiometer Analytical, Lyon, France). Three bottles were treated with copepodamides to induce increased toxin production [35] and three were used as controls. Copepodamides were extracted from freeze-dried Calanus finmarchius (Calanus AS, Troms $\varnothing$, Norway) as described in Selander et al. [35] and added to the cultures by coating the inside of the bottle with a copepodamide mixture dissolved in methanol to a final concentration of $2 \mathrm{nM}$. Due to slow release and rapid degradation the average effective concentration is around $1-2 \%$ of the added concentration [18]. The methanol was evaporated using $\mathrm{N}_{2}$ gas and the cultures transferred to the bottles after gentle mixing. Cultures were gently transferred to a freshly coated flasks every 24 hours during the treatment period to assure a continuous exposure to the cues [18]. The controls received the same treatment but 
cell abundance and nitrogen concentration while samples for toxin analysis and cellular carbon and nitrogen were taken at inoculation and in conjunction with the six video experiments (see below) during the course of the experiment. Initial samples of cellular toxin, carbon-, and nitrogen content were taken from the stock culture.

\section{Chemostat experiments}

While nutrient concentration declines over time in batch cultures, they are near constant in a continuous culture, thus allowing us to examine costs and benefits of grazer induction at constant concentrations of nutrients. Dinoflagellates do not tolerate vigorous mixing [37], so a classical chemostat cannot be used. Instead, we used exponentially fed batch cultures [38]. The exponentially fed batch culture (hereafter referred to as 'chemostat') is similar to a chemostat except that there is no continuous outflow. The volume is instead reduced to the initial volume at each sampling occasion after gently mixing the culture. Growth medium is added continuously in a constant proportion of the increasing volume of the culture by exponentially increasing the inflow using a computer controllable multichannel peristaltic pump (IPC 16, Ismatec, Wertheim, Germany).

Six replicate chemostat cultures of $A$. minutum were set up as in 1-L blue-cap glass bottles as described above. Depending on the dilution rate (DR), the initial culture volume varied between $250-500 \mathrm{~mL}$. Four different DR were used to vary cell growth rate: $0.05,0.10,0.20$, and $0.40 \mathrm{~d}^{-1}$. The inflow medium was $\mathrm{B} 1$ with reduced $(80 \mu \mathrm{M}) \mathrm{NO}_{3}{ }^{-}$in all the experiments except the first one $\left(0.10 \mathrm{~d}^{-1} \mathrm{DR}\right)$ where the $\mathrm{NO}_{3}{ }^{-}$concentration was $30 \mu \mathrm{M}$. We increased the nitrogen concentration in the subsequent experiments as this allowed more cells for analyses and because $\mathrm{pH}$ limitation turned out not to be a problem. The resulting ambient nitrogen concentration is independent on nitrogen content of the inflow medium (Appendix 1). The cultures were gently bubbled and $\mathrm{pH}$ was measured at each sampling occasion. At 
each DR, the cultures were allowed seven to ten days to achieve steady-state before starting the experimental treatment. In some cases perfect steady-state was not achieved.

The cultures were exposed to copepodamides daily as described above, using a nominal concentration of $0.63 \mathrm{nM}$. For the $0.2 \mathrm{~d}^{-1} \mathrm{DR}$ a second experiment was run with higher copepodamide concentration of $6 \mathrm{nM}$ to analyse the effect of increased exposure to grazers.

Samples for analysis of cell abundance and size, cell toxin content, cellular carbon and nitrogen, dissolved inorganic nitrogen, and copepod rejection rate were taken daily or every 2-3 days during the 6-10 day treatment period. Using the chemostat equations (Appendix 1) and assuming a maximum growth rate of $0.5 \mathrm{~d}^{-1}[39]$ and a half-saturation constant for nitrate of $0.5 \mu \mathrm{M}[40]$ the resulting nitrate concentration in the cultures should range from severe limitation to saturation. Thus, while nutrient concentration decrease over time in batch culture, it is more constant and controlled by the dilution rate in chemostats.

In the chemostats, the growth rate is controlled by the DR and any growth rate response will manifest as a change in the steady-state concentrations of cells and nutrients. Thus, if induced toxin production cause lower growth or nutrient affinity, the steady-state concentration of nutrients will increase and cell density decrease. The magnitude of the response can be computed from the chemostat equations (Appendix 1).

\section{Cell counts and cell size}

144 Cell concentrations were determined in acid Lugol (1\%) fixed samples. All cells in one $\mathrm{mL}$ or at least 400 cells were counted per replicate in a Sedgewick-Rafter chamber using an inverted microscope (Olympus, Tokyo, Japan). 20 random cells from each sample were measured at 400× magnification (width-length) and cell volume was estimated by assuming a prolatespheroid shape [41]. Cell growth was calculated from temporal differences in cell 
concentration assuming exponential growth. The dilution rate was accounted for when calculating growth in the chemostat experiments.

151

152

\section{Nitrate analysis}

Subsamples for nitrate analysis were filtered through a $0.2-\mu \mathrm{m}$ syringe filter, and stored frozen at $-20{ }^{\circ} \mathrm{C}$ until analysis. Nitrate was analysed by reduction to $\mathrm{NO}_{\mathrm{x}}$ with $\mathrm{VCl}_{3}$ as the reducing reagent [42] on a Smartchem 200 (AMS Alliance, Rome, Italy). Concentrations below $0.5 \mu \mathrm{M}$ were measured using an extended cuvette (100 mm, FireflySci, New York, New York, USA) by UV-VIS spectrophotometry.

\section{Toxin analysis}

Samples $(10-120 \mathrm{~mL})$ for cellular toxin contents were filtered onto $25 \mathrm{~mm}$ Whatman GF/F glass fibre filters and frozen at $-20{ }^{\circ} \mathrm{C}$ until extraction. $750 \mu \mathrm{L}$ of $0.05 \mathrm{M}$ acetic acid was added and samples were subjected to three freeze-thaw cycles to lyse cells. The extracts were filtered $(\mathrm{GF} / \mathrm{F})$ and stored at $-20^{\circ} \mathrm{C}$ until analysis. The samples from the batch experiment and the $0.2 \mathrm{~d}^{-1}$ DR experiments (both low and high dose) were analysed with isocratic ionpair chromatography followed by post-column derivatization and fluorescent detection [43].

We used a reversed phase C18 column $(150 \times 4 \mathrm{~mm} \mathrm{C18,} 5 \mu \mathrm{m}$, Dr. Maisch GmBH, Ammerbuch, Germany). Samples from the 0.05, 0.10, and $0.40 \mathrm{~d}^{-1} \mathrm{DR}$ experiments were separated on an Agilent 1200 HPLC (ZIC-HILIC, 2.1×150 mm, $5 \mu \mathrm{m}$, Merck KGaA, Darmstadt, Germany) and analysed by tandem mass spectrometry on a triple-quadrupole instrument (Agilent 6470) following the methods described in [44].

This particular strain of A. minutum is known to only produce gonyautoxins (GTX) 1-4 [2, 45]. GTX standards 1-4 were obtained from the Certified Reference Materials Program at National Research Council Canada (Halifax, Canada).

\section{Cellular carbon and nitrogen}


173 Samples for cellular C and N were filtered onto pre-combusted (550 ${ }^{\circ} \mathrm{C}, 2$ hours) $13 \mathrm{~mm}$

$174 \mathrm{GF} / \mathrm{C}$ filters, packed in tin capsules and dried for 24 hours at $60^{\circ} \mathrm{C}$. The samples were kept

175 dry at room temperature in a desiccator until analysis with a Thermo Scientific Flash 2000

176 Organic Elemental Analyzer (Thermo Fisher Scientific, Waltham, Massachusetts, USA).

177 Copepod feeding response

178 We directly observed individual copepod-cell interactions and recorded the fraction of

179 captured cells that were rejected. We used the feeding-current feeding copepod Temora

180 longicornis from a continuous culture that was maintained on a phytoplankton diet consisting of Rhodamonas salina, Thalassioria weissflogii, Heterocapsa triquetra, and Oxyrrhis marina.

Adult female copepods were tethered to a human hair by their dorsal surface using cyanoacrylate-based super glue [46]. The tethered copepods were starved overnight in darkness at the same temperature $\left(18^{\circ} \mathrm{C}\right)$ and salinity (26) as the cultures before being used for experiments. The tethered copepods are seemingly unaffected by the tethering and can live for many days while feeding, defecating, and producing eggs.

The feeding experiments took place in darkness. The untethered end of the hair was glued to a needle attached to a micromanipulator. The copepod was submerged in a $10 \times 10 \times 10 \mathrm{~cm}^{3}$ aquarium and Alexandrium cells were added to a final concentration of $100-200$ cells $\mathrm{mL}^{-1}$. The experiment started when cells were added. The water was gently mixed by a magnetic stirrer to keep the cells suspended. Three 10-minute sequences (0-10 minutes, 25-35 minutes, and 50-60 minutes) of $24 \mathrm{fps}$ footage was recorded during a one-hour period using a highspeed camera (Phantom V210; Vision Research, Wayne, New Jersey, USA) connected to a computer. The camera was equipped with lenses to get a field of view of $1.3 \times 1 \mathrm{~mm}^{2}$. The 
video sequences were analysed to quantify prey capture, ingestion, and the fraction of cells that were rejected by the copepod [46]. A new copepod was used for each replicate culture.

\section{Statistical analysis}

199

200

201

202

203

204

205

206

207

208

209

210

211

212

213

214

215

216

217

218

219

The effect of the copepodamide treatment in the batch-culture experiment was analysed using a generalized additive mixed model (GAMM) in the 'gamm4' R package [47]. 'Treatment' and 'Time' were used as fixed effects and 'Replicate' as the random effect.

To analyse the effect of the copepodamide treatment in the chemostat experiments, we used a linear mixed effects model with 'Time', 'Treatment', and 'Dilution rate' as fixed effects, and 'Replicate' as the random effect, in the 'ImerTest' R package [48]. The analysis of the repeated 'High' copepodamide-dose experiment was done separately. The Akaike information criterion was used to select the model that best fit the data. In case of a significant interaction between 'Dilution rate' and 'Treatment' a post-hoc test was made via pairwise comparisons by estimated marginal means using the Satterthwaite degrees of freedom method. The random-effect-variance component was close to zero for some variables, but retained in the model to incorporate the dependency of the response variable on the replications. Some variables were log-transformed to homogenize variances. Statistical tests were considered significant at the 0.05 level and are summarized in Appendix Tables $\mathrm{S} 1, \mathrm{~S} 2, \mathrm{~S} 3$ and S4.

\section{Results}

\section{Batch-culture experiment}

Cell abundance in the grazer-induced cultures increased faster than controls during the exponential phase (days 3-12; GAMM, $F=14.0, p<0.001$ ) and reached the stationary phase after around 14 days as the inorganic nitrogen in the cultures became depleted (Fig. 1a, c). The available nitrate in the culture medium was used up at a significantly higher rate in the 
induced treatment (Fig. 1c; GAMM, $F=9.7, p=0.003$ ), because cell accumulation rate in terms of cellular nitrogen was also faster in induced than in non-induced cultures (Appendix 2 Fig. S1; GAMM, $F=11.0, p=0.003)$. Cellular nitrogen content and cell sizes initially increased and then decreased as nutrients were exhausted and growth ceased, but induced cells had a significantly higher nitrogen content (Fig. 1d) and were significantly smaller (Fig. 1g, Appendix 2 Table S1) than non-induced cells during the exponential growth phase but converged with control cells after 10 and 16 days, respectively. Cellular carbon content was significantly higher in induced than in non-induced cells (Fig. 1e, Appendix 2 Table S1), resulting also in a faster accumulation of biomass during the exponential phase (Appendix 2 Fig. S1; GAMM, $F=61.8, p<0.001)$. The differences in cellular $\mathrm{C}$ and $\mathrm{N}$ contents between induced and non-induced cultures on a per-cell level showed the same pattern, but were less pronounced (Appendix 2 Fig. S1). The carbon to nitrogen ratio also increased in response to nitrate depletion but more markedly so in induced treatments (Fig. 1f). Overall, cellular nitrogen content increased and cellular carbon content decreased with increasing growth rate and the contents of both nitrogen and carbon were higher in induced cells (Fig. 2, Appendix Table S2).

Cell toxicity peaked after six days of exposure in the induced treatments with $400 \%$ higher GTX content than controls, after which it decreased throughout the rest of the exponential phase (Fig. 1h). Toxin production essentially reached zero after 14 days but cell toxicity remained stable at around $5-7$ amol $\mu \mathrm{m}^{-3}$ due to the low cell division rates. In the control treatment, cell toxicity followed the same temporal patterns but was lower throughout than in induced cells (Fig. 1h). Finally, a significantly higher fraction of induced than non-induced cells were rejected by copepods, demonstrating a clear benefit (Fig. 1i).

\section{Chemostat experiments}


Growth rate in the $0.05,0.10$, and $0.40 \mathrm{~d}^{-1}$ DR experiments were lower than the DR and cell concentrations thus decreased over time (Fig. 3). It was only in the two $0.20 \mathrm{~d}^{-1} \mathrm{DR}$ experiments that the cells were able to keep up with the DR (Fig. 3c, Fig. 4a). However, growth rates calculated from cell-bound nitrogen values per culture volume $\left(\mu \mathrm{g} \mathrm{N} \mathrm{mL}^{-1}\right)$ were nearly constant over time at the three lowest DR, and the growth rates were similar to the DR except at the lowest and highest DR (Figure 4b, Appendix 2 Fig. S2). The small differences in cell concentrations and the low sensitivity of estimates of affinity and maximum growth rate parameters to changes in cell concentration at low DR makes the estimation of these parameters meaningless (Appendix 1).

Consistent with the results of the batch-experiment results, induced cells were significantly smaller than non-induced cells at intermediate DR but similar at the lowest and highest rates. (Figure 4c). Cellular carbon increased and nitrogen contents decreased with growth rate and both were significantly higher in induced than non-induced cells, particularly at intermediate DR (Figure 4d, e, Fig. 2). Cellular C:N ratio varied inversely with DR and were slightly higher in induced than non-induced cells, all again consistent with the patterns in the batch experiment (Figure 4f, Fig. 2). As in the batch experiment, effects were similar but less pronounced when expressed on a per-cell basis (Appendix 2 Table S5, S6). The effect of varying the copepodamide dose from low $(0.63 \mathrm{nM})$ to high $(6 \mathrm{nM})$ in the $0.2 \mathrm{~d}^{-1} \mathrm{DR}$ a more comprehensive dose-response experiment (Appendix 3; Appendix 3. Fig. S1).

Cell toxin content increased in all but the 0.05 and $0.10 \mathrm{~d}^{-1} \mathrm{DR}$ experiments in response to copepodamides (Fig. 4g). Consequently, the copepods generally rejected a larger fraction of 
fraction of rejected cells increased with increasing toxin content but the effect saturates at a rather low toxin content of ca. 10 amol GTX $\mu \mathrm{m}^{-3}$ (Fig. 5).

\section{Discussion}

We set out to quantify the costs and benefits of toxin production in a dinoflagellate by comparing the performance of cells induced to express their defence with those that were not under different degrees of nitrogen limitation. Our experiments produced decreasing growth rates with increasing nitrogen limitation in both batch and chemostat cultures (Fig. 2a, c), and high C:N ratios in N-limited cells (Fig. 1f, Fig. 4f). We have utilized that toxin-production in many dinoflagellates, including A. minutum, can be induced by grazer cues [2, 35], thus allowing us to examine the same strain at different toxin-production rates. This is important because different strains of the same species may differ in many traits, including in their toxin profiles $[45,49]$. We note also that we examine the 'private-good' [50] grazer-deterrent effect of the defence at the level of the individual. That is, we quantify the benefits that only the individual cell that produces the toxin may benefit from. This is different from any toxic effects on the copepod that reduce its ability to graze on further cells, which is a 'public good', as also cells not producing the toxin may benefit [50]. We had predicted that both benefits and costs would be small in nutrient-starved cells, that benefits would be large but costs relatively small in nutrient-replete cells, and that both benefits and costs would be high at intermediate nitrogen levels. In line with our hypothesis, toxin-induction was highest at intermediate nitrogen limitation, but we found no evidence of direct costs in terms of reduced growth rate.

\section{Defence trade-offs}

The benefits of toxin production were clear and largely followed the pattern predicted. Moreover, the results were consistent between the two types of experiments: induced cells 
have up to 3 times higher chance of being rejected by the copepod than non-induced cells, and the chance of rejection was positively correlated to the toxin content of the cells. This confirms previous reports of reduced grazing on induced dinoflagellates [2], but the demonstration at the individual cell level is novel. It is well established that nitrogen-starved cells produce no or very little toxins $[9,51]$ and, hence, gain little or no defensive benefits. In the batch experiment, cells remained toxic even in the stationary phase due to low cell division rate, but they did not produce new toxins. With low toxin content but high rejection fraction, the $0.1 \mathrm{~d}^{-1}$ DR experiment shows some odd behaviour. Thus, we cannot exclude the possibility that other defences, such as allelochemicals $[52,53]$, are also at play.

The efficiency of the defence was not as high as that reported for other strains and species of Alexandrium spp. Thus, Xu and Kiørboe [5] found that more than $90 \%$ of the cells of some toxic Alexandrium species/strains were rejected by a copepod, but also that other strains containing toxins were readily consumed by the copepod. Neither Xu et al. [46] nor Teegarden et al. [54] were consequently able to relate the efficiency of the defence to the composition and concentration of specific toxins in the cells of Alexandrium spp. Here, we have established a direct correlation between the cells' content of the GTX toxin and the efficiency of the defence in the same strain of Alexandrium minutum.

It has been notoriously difficult to demonstrate the cost part of defence trade-offs in phytoplankton [7], and this study is no exception, despite a novel approach. Ideally, 'costs' should be quantified in terms of reduced cell division rate. We found no reduction in the growth rate nor in nutrient affinity of the cells, even at nutrient-deplete conditions. The proportion of cellular nitrogen invested in toxins increased the more toxic the cells were (Appendix 2 Fig. S3), but this did not affect growth rate. 
However, we document a number of very clear effects of induction in addition to enhanced toxin production, i.e., elevated cellular contents of $\mathrm{C}$ and $\mathrm{N}$, a reduction in cell size, and even an increase in cell division rate, with the effects being most pronounced at intermediate nutrient levels. The responses are consistent between the batch and the continuous cultures.

The expectation of reduced cell division rate of grazer-induced, nitrogen-limited cells is based on the nitrogen requirements for PST production in Alexandrium tamarense as worked out by Chakraborty et al. [31]. However, A. tamarense produce 1-2 orders-of-magnitude more toxins than the A. minutum used here. Thus, the biochemical syntheses costs and the $\mathrm{N}$ requirements for toxins are correspondingly smaller in our experiment and the higher $\mathrm{N}$ uptake of induced cells cannot be explained by direct requirements for toxin production.

It is well established that cell size decrease when nutrient are limited $[55,56]$, as also seen most clearly in the batch experiment (Fig. 1g). However, cell volume shrink in response to grazer cues by up to $25 \%$ relative to non-induced cells. This has two implications. First, a smaller cell volume results in a higher concentration of toxins in the cells. It is reasonable to assume that the copepods respond to the concentration rather than the contents of toxins, and the shrinking of the cells may therefore be adaptive and part of the defence. A similar consistent response in cell size to grazer cues has been found in four species of diatoms [24]. For the diatoms, smaller cell sizes implies higher concentrations of biogenic silica and, therefore, a stronger protective shell that makes the cells less susceptible to copepod grazing [23].

The second potential implication of cell shrinking is a higher specific affinity for dissolved nutrients. To first order, specific affinity scales inversely with cell radius due to the nature of molecular diffusion [57] and it is well established experimentally that the volume-specific nutrient uptake indeed increases with decreasing cell size $[58,59]$. Thus, a $25 \%$ decrease in 
cell volume, corresponds to an $8 \%$ decrease in radius and a corresponding increase in specific affinity. This, in fact, may account for the elevated nitrogen uptake, nitrogen content, and growth rate of induced cells when cells start being nutrient limited, as most clearly seen in the batch experiment (Fig. 1). If the decrease in cell size is an adaptation to increased toxin concentration, then the elevated nitrogen assimilation and growth rate of induced cells is a secondary and beneficiary effect.

The increased carbon content found in induced cells may be due to thickening of their thecal plates, providing them with another possible defence. It is unclear if this has an effect on the copepods, but it has been shown that diatoms that increase their silica shell thickness experience reduced grazing from both juvenile and adult copepods [23].

\section{Ecological and indirect costs of defence}

While we were unable to demonstrate direct costs of toxin production even in nitrogenstarved cells, defences may come with indirect ecological costs that do not manifest in simplified laboratory settings [21]. This includes, e.g., increased sinking rate or reduced swimming speed that may inflict fitness costs in nature [60, 61]. A possible ecological cost of the reduced cell size recorded here is elevated predation risk. In general, mortality rate of plankton organisms scale inversely with their volume to power 0.25 [62], and a $25 \%$ decrease in volume thus implies a $7.5 \%$ increase in predation mortality from other predators than copepods. Copepods and other larger herbivores are probably the most important grazers on dinoflagellates, thus the more than 50\% decrease in copepod grazing pressure of induced cells more than outweighs the cost in most situations, and toxin production increases the fitness of the cell.

Theory of defences predicts that defences should only be inducible if they are associated with a cost [63]. The number of studies unable to detect costs associated with induced toxin 
production in phytoplankton suggests that additional factors may be at play. Recent advancements in genome sequencing reveals that a substantial part of the genome may be dedicated to secondary metabolism, up to one fifth in some cyanobacteria [64]. Keeping a single biosynthetic pathway active may inflict a very limited cost whereas the cost for constant activation of one fifth of the genome will be substantial [65]. Thus, the evolution of inducible defence may be driven not by the allocation of resources to a single pathway, but the necessity to avoid allocation to all defence systems simultaneously. This is but a corollary hypothesis to the optimal defence theory, but one that may explain the lack of detectable costs in some induced responses to herbivory.

In conclusion, we found a diverse nutrient-dependent response of a dinoflagellate to copepod cues: increased toxicity with implied lower predation risk, higher cellular contents of carbon and nitrogen, reduced cell size, and higher growth rate. Most of these responses may be beneficial to the cells, while we found no indication of direct costs. Because dinoflagellates are not Darwinian demons, the necessary costs are most likely indirect or ecological that are apparent only in nature.

\section{Acknowledgements}

The Centre for Ocean Life is supported by the Villum Foundation. ES was funded by Swedish Research Council VR no. 2019-05238. We thank Benni Winding Hansen for CHN measurements, Jack Melbye for maintaining copepod cultures, Colin Stedmon for assistance with $\mathrm{NO}_{3}{ }^{-}$measurements, Josephine Grønning for copepodamide extractions, Aurore Maureaud for providing the script for the mixed model, Daniël van Denderen for providing statistical assistance, and Per Juel Hansen for rewarding discussions.

\section{Conflict of interest}

We declare we have no conflict of interest. 


\section{References:}

1. Llewellyn LE. Saxitoxin, a toxic marine natural product that targets a multitude of receptors. Nat Prod Rep 2006; 23: 200-218.

2. Selander E, Thor P, Toth G, Pavia H. Copepods induce paralytic shellfish toxin production in marine dinoflagellates. Proc $R$ Soc B 2006; 273: 1673-1680.

3. Turner JT, Tester PA. Toxic marine phytoplankton, zooplankton grazers, and pelagic food webs. Limnol Oceanogr 1997; 42: 1203-1213.

4. Smetacek V. A Watery Arms Race. Nature 2001; 441: 745.

5. Xu J, Kiørboe T. Toxic dinoflagellates produce true grazer deterrents. Ecology 2018; 99: 22402249.

6. Cusick KD, Widder EA. Bioluminescence and toxicity as driving factors in harmful algal blooms: Ecological functions and genetic variability. Harmful Algae 2020; 98: 101850.

7. Pančić M, Kiørboe T. Phytoplankton defence mechanisms: traits and trade-offs: Defensive traits and trade-offs. Biol Rev 2018; 93: 1269-1303.

8. John EH, Flynn KJ. Growth dynamics and toxicity of Alexandrium fundyense (Dinophyceae): the effect of changing N:P supply ratios on internal toxin and nutrient levels. Eur J Phycol 2000; 35: 11-23.

9. Selander E, Cervin G, Pavia H. Effects of nitrate and phosphate on grazer-induced toxin production in Alexandrium minutum. Limnol Oceanogr 2008; 53: 523-530.

10. Blossom HE, Markussen B, Daugbjerg N, Krock B, Norlin A, Hansen PJ. The Cost of Toxicity in Microalgae: Direct Evidence From the Dinoflagellate Alexandrium. Front Microbiol 2019; 10: 1065 .

11. Brown ER, Kubanek J. Harmful alga trades off growth and toxicity in response to cues from dead phytoplankton. Limnol Oceanogr 2020; lno.11414.

12. Windust AJ, Wright JLC, McLachlan JL. The effects of the diarrhetic shellfish poisoning toxins, okadaic acid and dinophysistoxin-1, on the growth of microalgae. Mar Biol 1996; 126: 19-25. 
13. Legrand C, Rengefors K, Fistarol GO, Granéli E. Allelopathy in phytoplankton - biochemical, ecological and evolutionary aspects. Phycologia 2003; 42: 406-419.

14. John E, Flynn K. Modelling changes in paralytic shellfish toxin content of dinoflagellates in response to nitrogen and phosphorus supply. Mar Ecol Prog Ser 2002; 225: 147-160.

15. Lundholm N, Krock B, John U, Skov J, Cheng J, Pančić M, et al. Induction of domoic acid production in diatoms_-Types of grazers and diatoms are important. Harmful Algae 2018; 79: 64-73.

16. Bergkvist J, Selander E, Pavia H. Induction of toxin production in dinoflagellates: the grazer makes a difference. Oecologia 2008; 156: 147-154.

17. Griffin JE, Park G, Dam HG. Relative importance of nitrogen sources, algal alarm cues and grazer exposure to toxin production of the marine dinoflagellate Alexandrium catenella. Harmful Algae 2019; 84: 181-187.

18. Selander E, Berglund EC, Engström P, Berggren F, Eklund J, Harðardóttir S, et al. Copepods drive large-scale trait-mediated effects in marine plankton. Sci Adv 2019; 5: eaat5096.

19. Rhoades DF. Evolution of plant chemical defense against herbivores. Herbivores: Their Interaction with Secondary Plant Metabolites. 1979. Academic Press, New York, NY, pp 1-55.

20. Karban R. The ecology and evolution of induced resistance against herbivores: Induced resistance against herbivores. Funct Ecol 2011; 25: 339-347.

21. Strauss SY, Rudgers JA, Lau JA, Irwin RE. Direct and ecological costs of resistance to herbivory. TREE 2002; 17: 278-285.

22. Agrawal AA. Current trends in the evolutionary ecology of plant defence. Funct Ecol 2011; 25: $420-432$.

23. Pančić M, Torres RR, Almeda R, Kiørboe T. Silicified cell walls as a defensive trait in diatoms. Proc R Soc B 2019; 286: 20190184.

24. Grønning J, Kiørboe T. Diatom defence: Grazer induction and cost of shell-thickening. Funct Ecol 2020; 1365-2435.13635.

25. Kiørboe T, Andersen KH. Nutrient affinity, half-saturation constants and the cost of toxin production in dinoflagellates. Ecol Lett 2019; 22: 558-560. 
26. Wang X, Wang Y, Ou L, He X, Chen D. Allocation Costs Associated with Induced Defense in Phaeocystis globosa (Prymnesiophyceae): the Effects of Nutrient Availability. Sci Rep 2015; 5: 10850

27. Zhu X, Wang J, Chen Q, Chen G, Huang Y, Yang Z. Costs and trade-offs of grazer-induced defenses in Scenedesmus under deficient resource. Sci Rep 2016; 6: 22594.

28. Redfield AC. The biological control of chemical factors in the environment. Am Sci 1958; 46: $205-221$

36. Hansen PJ. The red tide dinoflagellate Alexandrium tamarense: effects on behaviour and growth 
37. Berdalet E, Peters F, Koumandou VL, Roldán C, Guadayol Ò, Estrada M. Species-specific physiological response of dinoflagellates to quantified small-scale turbulence ${ }^{1}$. J Phycol 2007; 43: $965-977$.

38. Fischer R, Andersen T, Hillebrand H, Ptacnik R. The exponentially fed batch culture as a reliable alternative to conventional chemostats. Limnol Oceanogr Meth 2014; 12: 432-440.

39. Flynn K, Jones KJ, Flynn KJ. Comparisons among species of Alexandrium (Dinophyceae) grown in nitrogen- or phosphorus-limiting batch culture. Mar Biol 1996; 126: 9-18.

40. Brandenburg KM, Wohlrab S, John U, Kremp A, Jerney J, Krock B, et al. Intraspecific trait variation and trade-offs within and across populations of a toxic dinoflagellate. Ecol Lett 2018; 21: $1561-1571$.

41. Hillebrand H, Dürselen C-D, Kirschtel D, Pollingher U, Zohary T. Biovolume Calculation for Pelagic and Benthic Microalgae. J Phycol 1999; 35: 403-424.

42. Schnetger B, Lehners C. Determination of nitrate plus nitrite in small volume marine water samples using vanadium(III)chloride as a reduction agent. Mar Chem 2014; 160: 91-98.

43. Asp TN, Larsen S, Aune T. Analysis of PSP toxins in Norwegian mussels by a post-column derivatization HPLC method. Toxicon 2004; 43: 319-327.

44. Turner A, Tölgyesi L. Determination of Paralytic Shellfish Toxins and Tetrodotoxin in Shellfish using HILIC/MS/MS (Application Note No. 5994-0967EN). 2019.

45. Franco JM, Fernández P, Reguera B. Toxin profiles of natural populations and cultures of Alexandrium minutum Halim from Galician (Spain) coastal waters. J Appl Phycol 1994; 6: 275279.

46. Xu J, Hansen PJ, Nielsen LT, Krock B, Tillmann U, Kiørboe T. Distinctly different behavioral responses of a copepod, Temora longicornis, to different strains of toxic dinoflagellates, Alexandrium spp. Harmful Algae 2017; 62: 1-9.

47. Wood S, Scheipl F. gamm4: Generalized additive mixed models using mgev and lme4. 2020.

48. Kuznetsova A, Brockhoff PB, Christensen RHB. ImerTest Package: Tests in Linear Mixed Effects Models. J Stat Soft 2017; 82. 
49. Wohlrab S, Selander E, John U. Predator cues reduce intraspecific trait variability in a marine dinoflagellate. BMC Ecol 2017; 17: 8 .

50. Driscoll WW, Hackett JD, Ferrière R. Eco-evolutionary feedbacks between private and public goods: evidence from toxic algal blooms. Ecol Lett 2016; 19: 81-97.

51. Flynn K, Franco J, Fernandez P, Reguera B, Zapata M, Wood G, et al. Changes in toxin content, biomass and pigments of the dinoflagellate Alexandrium minutum during nitrogen refeeding and growth into nitrogen or phosphorus stress. Mar Ecol Prog Ser 1994; 111: 99-109.

52. Tillmann U, John U. Toxic effects of Alexandrium spp. on heterotrophic dinoflagellates: an allelochemical defence mechanism independent of PSP-toxin content. Mar Ecol Prog Ser 2002; 230: $47-58$.

53. Tillmann U, Hansen PJ. Allelopathic effects of Alexandrium tamarense on other algae: evidence from mixed growth experiments. Aquat Microb Ecol 2009; 57: 101-112.

54. Teegarden GJ, Campbell RG, Anson DT, Ouellett A, Westman BA, Durbin EG. Copepod feeding response to varying Alexandrium spp. cellular toxicity and cell concentration among natural plankton samples. Harmful Algae 2008; 7: 33-44.

55. Peter KH, Sommer U. Interactive effect of warming, nitrogen and phosphorus limitation on phytoplankton cell size. Ecol Evol 2015; 5: 1011-1024.

56. Garcia NS, Bonachela JA, Martiny AC. Interactions between growth-dependent changes in cell size, nutrient supply and cellular elemental stoichiometry of marine Synechococcus. ISME J 2016; 10: 2715-2724.

57. Kiørboe T. Turbulence, Phytoplankton Cell Size, and the Structure of Pelagic Food Webs. Adv Mar Biol 1993; 29: 1-72.

58. Lindemann C, Fiksen $\varnothing$, Andersen KH, Aksnes DL. Scaling Laws in Phytoplankton Nutrient Uptake Affinity. Front Microbiol 2016; 3: 1-6.

59. Edwards KF, Thomas MK, Klausmeier CA, Litchman E. Allometric scaling and taxonomic variation in nutrient utilization traits and maximum growth rate of phytoplankton. Limnol Oceanogr 2012; 57: 554-566. 
521 60. Lürling M, Van Donk E. Grazer-induced colony formation in Scenedesmus: are there costs to $522 \quad$ being colonial? Oikos 2000; 88: 111-118.

523 61. Selander E, Jakobsen HH, Lombard F, Kiorboe T. Grazer cues induce stealth behavior in marine 524 dinoflagellates. Proc Natl Acad Sci USA 2011; 108: 4030-4034.

525 62. Kiørboe T. A Mechanistic Approach to Plankton Ecology. 2008. Princeton University Press, $526 \quad$ Princeton, NJ.

527 63. Tollrian R, Harvell CD. The Ecology and Evolution of Inducible Defenses. 1999. Princeton $528 \quad$ University Press, Princeton, NJ.

529 64. Leao T, Castelão G, Korobeynikov A, Monroe EA, Podell S, Glukhov E, et al. Comparative 530 genomics uncovers the prolific and distinctive metabolic potential of the cyanobacterial genus $531 \quad$ Moorea. Proc Natl Acad Sci USA 2017; 114: 3198-3203.

532 65. Züst T, Agrawal AA. Trade-Offs Between Plant Growth and Defense Against Insect Herbivory: An Emerging Mechanistic Synthesis. Annu Rev Plant Biol 2017; 68: 513-534. 


\section{Figure legends.}

536 Figure 1. Change in (a) cell abundance (cells $\left.\mathrm{mL}^{-1}\right),\left(\right.$ b) growth rate $\left(\mathrm{d}^{-1}\right)$, (c) culture nitrate

537 concentration $(\mu \mathrm{M}),(\mathrm{d})$ cell nitrogen content $\left(\mathrm{pg} \mathrm{N} \mathrm{\mu m}^{-3}\right)$, (e) cell carbon content $(\mathrm{pg} \mathrm{C}$

$538 \mu \mathrm{m}^{-3}$ ), (f) $\mathrm{C}: \mathrm{N}$ ratio, (g) cell volume $\left(\mu \mathrm{m}^{-3}\right)$, (h) cell toxin content (amol $\mu \mathrm{m}^{-3}$ ), and (i) the

539 fraction of cells rejected by copepods over time in the batch-culture experiment. Light grey

540 points in (d), (e), (f), and (h) are initial values from the stock culture. Values are means and

541 error bars are standard error $(n=3)$.

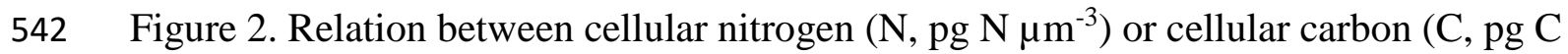

$\left.543 \mu \mathrm{m}^{-3}\right)$, and growth rate $\left(\mathrm{GR}, \mathrm{d}^{-1}\right)$ in the $(\mathrm{a}, \mathrm{b})$ batch-culture and $(\mathrm{c}, \mathrm{d})$ chemostat experiments.

544 Growth rate is calculated from change in biovolume. Multiple linear regression (with 95\%

545 confidence intervals) was fit to the data: (a) control: $\log$ cell $\mathrm{N}=-1.594+0.420 \times \mathrm{GR}$,

546 induced: $\log$ cell $\mathrm{N}=-1.497+0.420 \times \mathrm{GR}\left(\mathrm{R}^{2}=0.27, p=0.002\right) ;(\mathrm{b})$ control: $\log$ cell $\mathrm{C}=$

$547-0.684-0.181 \times \mathrm{GR}$, induced: $-0.561-0.181 \times \mathrm{GR}\left(\mathrm{R}^{2}=0.539, p<0.001\right) ;(\mathrm{c})$ control: $\log$

cell $\mathrm{N}=-1.546+0.363 \times \mathrm{GR}$, induced: $-1.456+0.363 \times \mathrm{GR}\left(\mathrm{R}^{2}=0.28, p<0.001\right) ;$ and $(\mathrm{d})$

control: $\log$ cell $\mathrm{C}=-0.594-0.654 \times \mathrm{GR}$, induced: $-0.479-0.654 \times \mathrm{GR}\left(\mathrm{R}^{2}=0.61, p<\right.$

$550 \quad 0.001)$.

551 Figure 3. Change in cell abundance $\left(\right.$ cells $\left.\mathrm{mL}^{-1}\right)$ in the chemostats at the different dilution

552 rates. (a) $0.05 \mathrm{~d}^{-1}$, (b) $0.10 \mathrm{~d}^{-1}$, (c) $0.20 \mathrm{~d}^{-1}$ with high $(6 \mathrm{nM})$ and low $(0.63 \mathrm{nM})$ dose of

553 copepodamides, (d) $0.40 \mathrm{~d}^{-1}$. The values are means and error bars show standard error $(\mathrm{n}=$

554 3). Note the different y-axes scales.

555 Figure 4. Summary of (a) cell growth rate $\left(\mathrm{d}^{-1}\right)$, (b) N-specific growth rate $\left(\mathrm{d}^{-1}\right)$, (c) cell

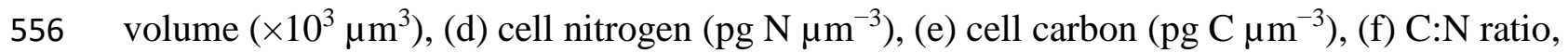

557 (g) cell toxin content $\left(\mathrm{amol} \mu \mathrm{m}^{-3}\right)$, and $(\mathrm{h})$ the fraction of cells rejected by copepods in the

558 chemostat experiments. Values are averaged over time during the treatment period and error 
559 bars show standard deviation $\left(n=4\right.$ in $0.05,0.20,0.40 \mathrm{~d}^{-1} ; \mathrm{n}=5$ in $0.10 \mathrm{~d}^{-1} ; \mathrm{n}=3$ in $0.10 \mathrm{~d}^{-1}$

$560 \mathrm{C} / \mathrm{N}$ measurements). Asterisks above bars indicate significant differences between treatments

561 within dilution rates $(* * * p<0.001, * * p<0.01, * p<0.05)$. In (j) and all $0.2 \mathrm{~d}^{-1}$ high they

562 indicate significant effect of the 'Treatment' factor. Further statistical analysis is reported in

563 the appendix.

564 Figure 5. Relation between copepod rejection rate and cell toxin content (GTX) normalized

565 by volume $\left(\mathrm{amol} \mu \mathrm{m}^{-3}\right)$. Data are from both batch culture and chemostat experiments. The

566 regression line (with 95\% confidence intervals) is Rejection $=0.320+0.219 \times \log$ GTX $\left(\mathrm{R}^{2}\right.$

$567=0.42, p<0.001)$. Due to odd behaviour, data from the $0.10 \mathrm{~d}^{-1}$ chemostat experiment

568 (triangles) are not included in the regression. Including them does not change the significant

569 effect $\left(\mathrm{R}^{2}=12, p<0.001\right)$. 

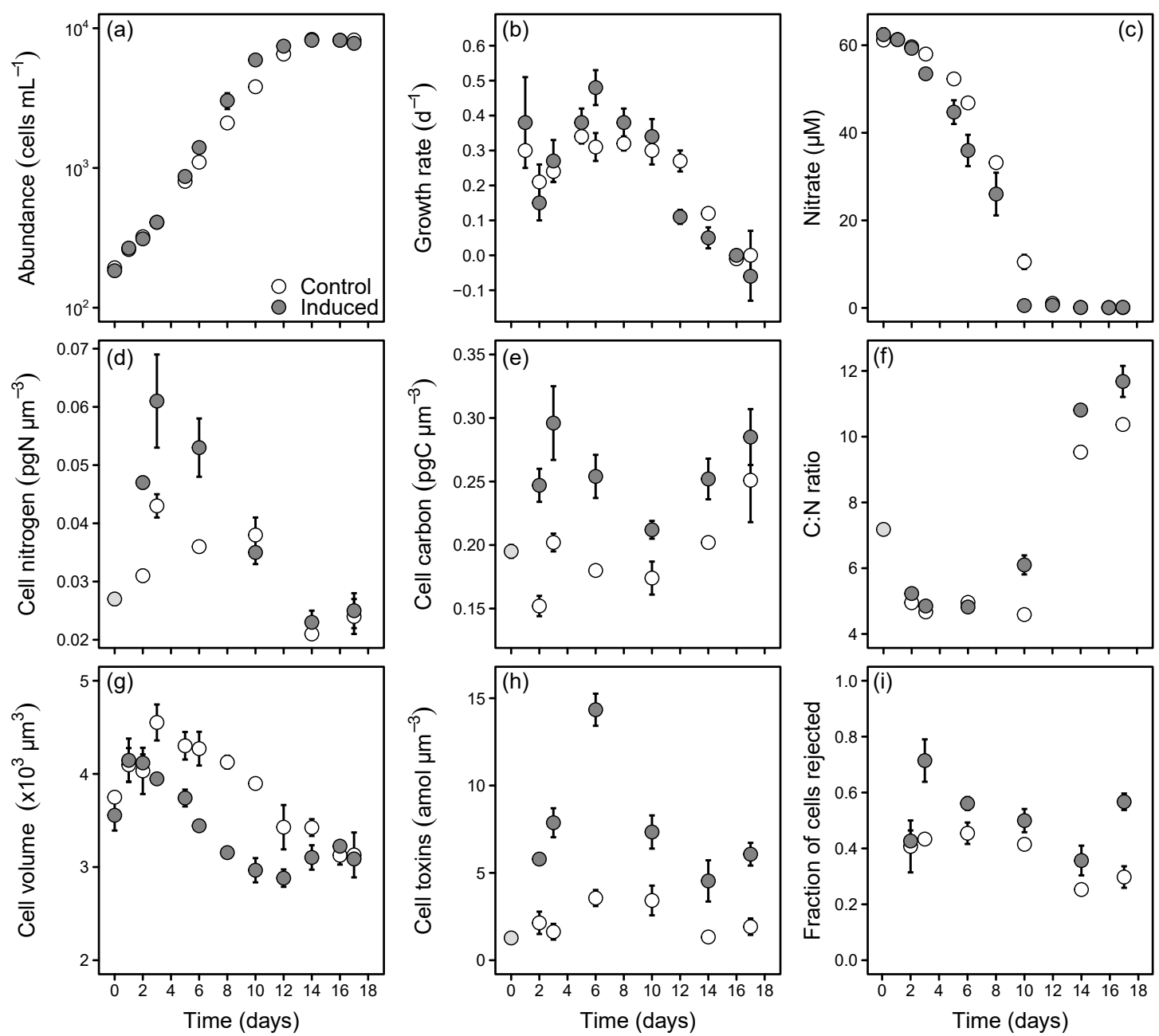

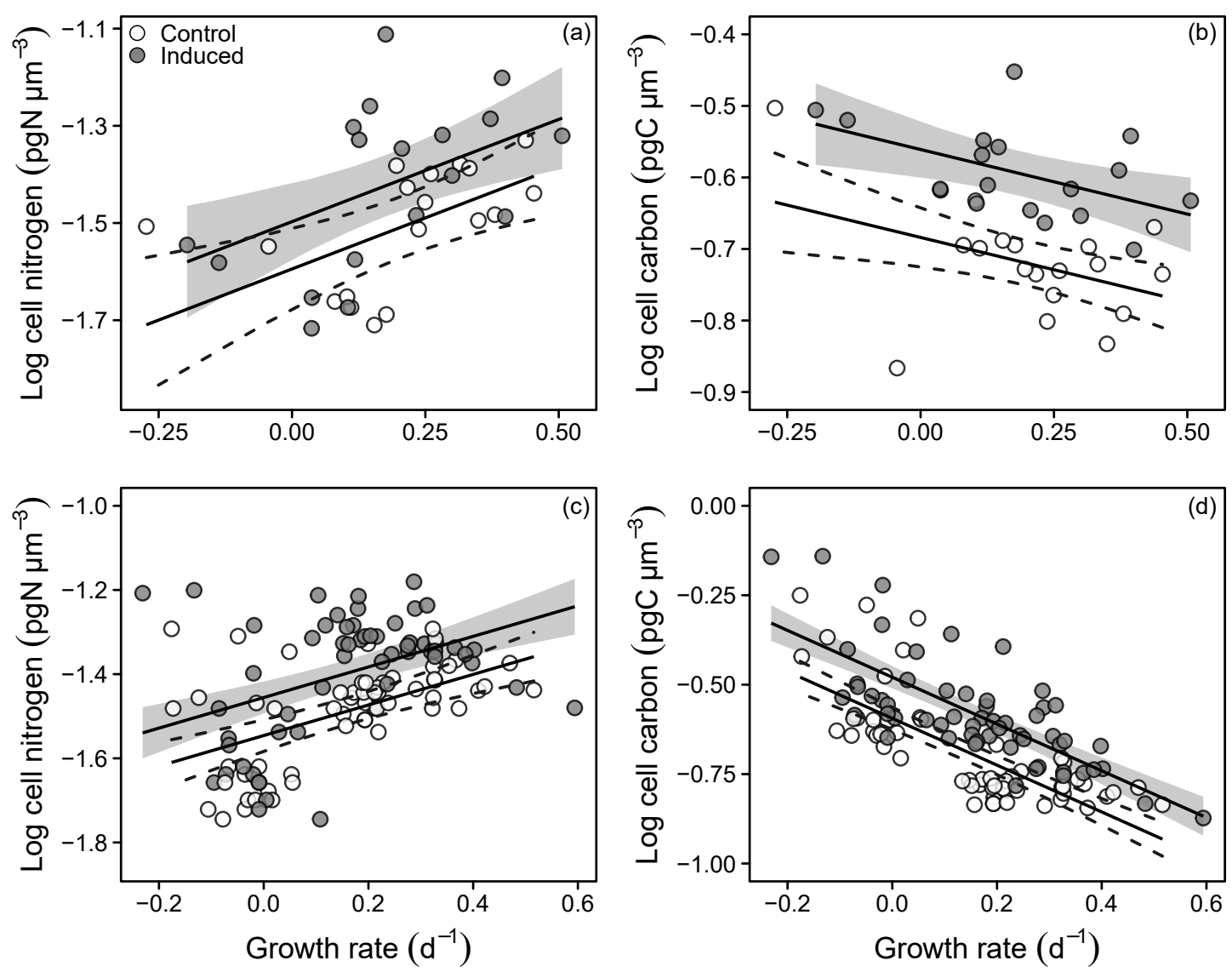


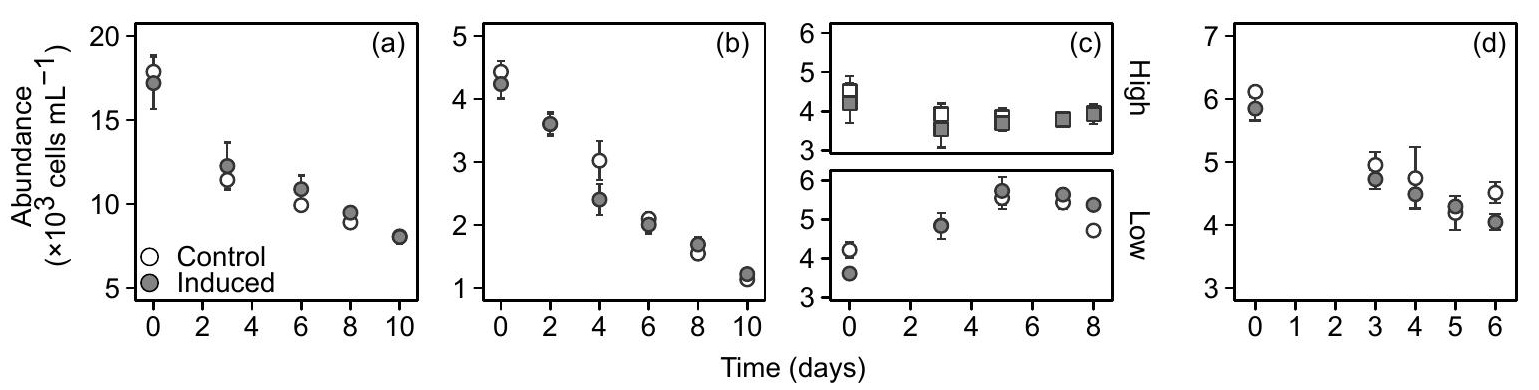




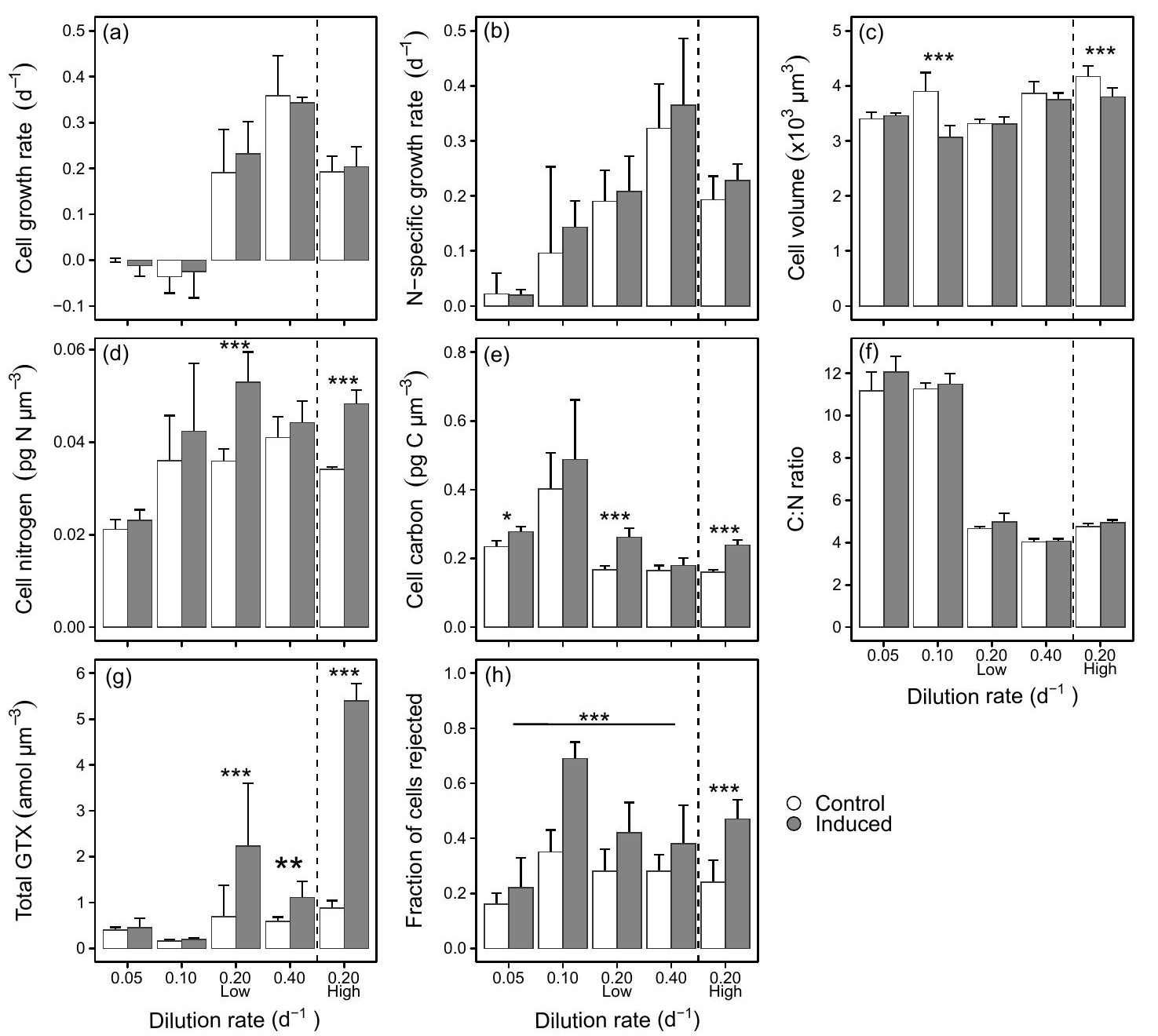




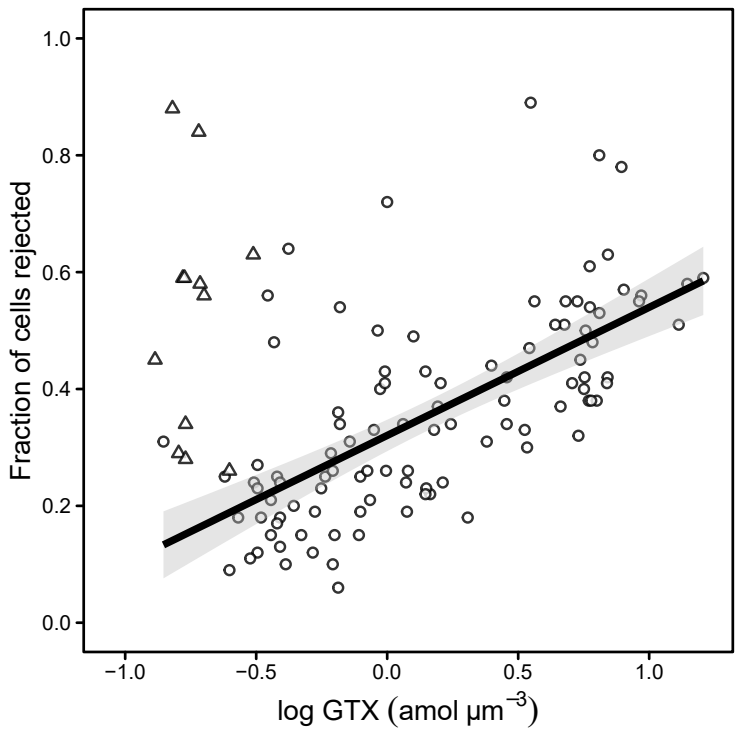




\section{Supplementary Information}

\section{Appendix 1.}

The chemostat equation assuming a Michaelis-Menten functional response in nutrient uptake to nutrient concentration reads

$$
\begin{aligned}
& \frac{d B}{d t}=\mu_{\max }\left(\frac{\alpha N(t)}{\mu_{\max }+\alpha N(t)}\right) B-D B \\
& \frac{d N}{d t}=-\mu_{\max }\left(\frac{\alpha N(t)}{\mu_{\max }+\alpha N(t)}\right) B+D\left(N_{i}-N(t)\right),
\end{aligned}
$$

where $B$ is the phytoplankton biomass in culture (as cellular mol of nitrogen $\operatorname{vol}^{-1}$ ), $D$ is the dilution rate $\left(\right.$ time $\left.^{-1}\right), \mu_{\max }$ the maximum growth rate $\left(\right.$ time $\left.^{-1}\right), \alpha$ the affinity for nitratenitrogen (vol cellular mol of nitrogen ${ }^{-1}$ time $^{-1}$ ), $N$ the nutrient concentration in culture (mol $\mathrm{N} \mathrm{vol}^{-1}$ ), and $N_{i}$ the nutrient concentration in inflow water (mass $\mathrm{vol}^{-1}$ ). Solving for steady state yields

$$
\begin{aligned}
& \widehat{N}=\frac{D \mu_{\max }}{\alpha\left(\mu_{\max }-D\right)} \\
& \widehat{B}=N_{i}-\frac{D \mu_{\max }}{\alpha\left(\mu_{\max }-D\right)}=N_{i}-\widehat{N} .
\end{aligned}
$$

While eq. (3) and (4) are two equations with two unknowns $\left(\mu_{\max }, \alpha\right)$, they are not independent and one cannot find both unknowns. With one fixed, one can compute the other.

If the cells respond to a cue by lowering their maximum growth rate and/or its affinity then in the chemostat at steady state the concentration of nutrient will increase, and the density of cells decrease. Assuming first that the response is solely in the maximum growth rate, we can compute the response from the new steady state concentrations, dilution rate, and (known) affinity by solving either eq. (3) or eq. (4) for $\mu_{\max }$ : 


$$
\mu_{\max }=\frac{\widehat{N} \alpha D}{\widehat{N} \alpha-D} \text { or } \mu_{\max }=\frac{D \alpha\left(N_{i}-\widehat{B}\right)}{\alpha\left(N_{i}-\widehat{B}\right)-D}
$$

Alternatively, assume that the cells respond by lowering their affinity, then we can similarly compute the response in affinity from the steady state concentrations, the - known or assumed - maximum growth rate, and dilution rate:

$$
\alpha=\frac{D \mu_{\max }}{\widehat{N}\left(\mu_{\max }-D\right)} \text { or } \alpha=\frac{-D \mu_{\max }}{\hat{B}\left(\mu_{\max }-D\right)-N_{i}\left(\mu_{\max }+D\right)} \text {. }
$$

Due to the shape of the functional response, these equations do not provide accurate absolute estimates, but do provide estimates of relative changes in maximum growth rate or affinity. However, and unfortunately, for low dilution rates, where according to our hypothesis changes in the parameters in response to grazer cues is expected to be largest, steady state cell concentrations are not very sensitive to changes in the parameters. 


\section{Supplementary Information}

\section{Appendix 2}

Appendix 2 Table S1. Summary statistics for the generalized additive mixed model (GAMM) used to assess the effect of the copepodamide treatment in the batch experiment.

\begin{tabular}{|c|c|c|c|c|c|}
\hline & & Estimate & Std. error & t value & $P$ \\
\hline \multirow[t]{2}{*}{ Cell abundance } & Intercept & 3356.70 & 124.2 & 27.02 & $<0.001$ \\
\hline & Treatment & 312.10 & 175.7 & 1.78 & 0.081 \\
\hline \multirow[t]{2}{*}{ Growth rate } & Intercept & 0.22 & 0.01 & 15.40 & $<0.001$ \\
\hline & Treatment & -0.01 & 0.02 & -0.27 & 0.790 \\
\hline \multirow[t]{2}{*}{ Cell volume } & Intercept & 3844.59 & 40.24 & 95.54 & $<0.001$ \\
\hline & Treatment & -397.48 & 56.91 & -6.99 & $<0.001$ \\
\hline \multirow[t]{2}{*}{ Nitrate } & Intercept & 31.98 & 0.72 & 44.22 & $<0.001$ \\
\hline & Treatment & -3.17 & 1.02 & -3.11 & 0.003 \\
\hline \multirow[t]{2}{*}{ Cell nitrogen } & Intercept & 0.032 & 0.001 & 24.31 & $<0.001$ \\
\hline & Treatment & 0.007 & 0.002 & 3.97 & $<0.001$ \\
\hline \multirow[t]{2}{*}{ Cell carbon } & Intercept & 0.193 & 0.006 & 30.77 & $<0.001$ \\
\hline & Treatment & 0.055 & 0.009 & 6.22 & $<0.001$ \\
\hline \multirow[t]{2}{*}{$\mathrm{C}: \mathrm{N}$ ratio } & Intercept & 6.61 & 0.07 & 89.99 & $<0.001$ \\
\hline & Treatment & 0.63 & 0.10 & 6.08 & $<0.001$ \\
\hline \multirow[t]{2}{*}{ Cell toxin } & Intercept & 2.18 & 0.33 & 6.68 & $<0.001$ \\
\hline & Treatment & 4.57 & 0.46 & 9.88 & $<0.001$ \\
\hline \multirow[t]{2}{*}{ Rejection } & Intercept & 0.38 & 0.03 & 13.82 & $<0.001$ \\
\hline & Treatment & 0.15 & 0.04 & 3.89 & $<0.001$ \\
\hline
\end{tabular}


Appendix 2 Table S2. Summary statistics for multiple regression analysis on the relationship between $\log$ cell nitrogen $\left(\mathrm{pg} \mathrm{N} \mu \mathrm{m}^{-3}\right)$ or $\log$ carbon $\left(\operatorname{pg~C} \mu \mathrm{m}^{-3}\right)$, and growth $\left(\mathrm{d}^{-1}\right)$ in the batch and chemostat experiments. Growth rate is based om change in biovolume $\left(\mu \mathrm{m}^{3} \mathrm{~mL}^{-1}\right)$. 'Lower' and 'Upper' refers to 95\% confidence intervals.

\begin{tabular}{|c|c|c|c|c|c|c|c|}
\hline & & & Estimate & Std. Error & Lower & Upper & $P$ \\
\hline \multirow[t]{6}{*}{ Batch } & $\begin{array}{l}\text { Log cell } \\
\text { nitrogen }\end{array}$ & Intercept & -1.594 & 0.041 & -1.677 & -1.512 & $<0.001$ \\
\hline & & Growth & 0.420 & 0.126 & 0.164 & 0.678 & 0.002 \\
\hline & & Treatment & 0.097 & 0.044 & 0.008 & 0.187 & 0.034 \\
\hline & Log cell carbon & Intercept & -0.684 & 0.020 & -0.725 & -0.643 & $<0.001$ \\
\hline & & Growth & -0.181 & 0.062 & -0.307 & -0.054 & 0.007 \\
\hline & & Treatment & 0.123 & 0.022 & 0.078 & 0.167 & $<0.001$ \\
\hline \multirow[t]{6}{*}{ Chemostat } & $\begin{array}{l}\text { Log cell } \\
\text { nitrogen }\end{array}$ & Intercept & -1.546 & 0.019 & -1.584 & -1.508 & $<0.001$ \\
\hline & & Growth & 0.363 & 0.067 & 0.230 & 0.497 & $<0.001$ \\
\hline & & Treatment & 0.090 & 0.022 & 0.045 & 0.135 & $<0.001$ \\
\hline & Log cell carbon & Intercept & -0.594 & 0.016 & -0.625 & -0.563 & $<0.001$ \\
\hline & & Growth & -0.654 & 0.055 & -0.764 & -0.545 & $<0.001$ \\
\hline & & Treatment & 0.115 & 0.017 & 0.078 & 0.152 & $<0.001$ \\
\hline
\end{tabular}


Appendix 2 Table S3. Type III analysis of variance (ANOVA) on the fixed effects in the linear mixed models used to analyze the effect of the copepodamide treatment in high dose (6 $\mathrm{nM}$ ) repeated $0.2 \mathrm{~d}^{-1}$ dilution rate chemostat experiment. $P$-values are provided via Satterthwaite's degrees of freedom method. Data on the fraction of rejected cells was logtransformed to homogenize variances.

\begin{tabular}{llcccrc}
\hline & Fixed effects & Sum Sq. & NumDF & DenDF & F & $P$ \\
\hline Cell volume* & Treatment & 835147 & 1 & 21 & 27.998 & $<0.001$ \\
& Time & 431937 & 1 & 21 & 14.480 & 0.001 \\
\hline Cell growth rate & Treatment & 0.0007 & 1 & 4 & 0.21 & 0.674 \\
& Time & 0.0160 & 1 & 17 & 4.84 & 0.042 \\
\hline $\begin{array}{l}\text { N-specific growth } \\
\text { rate }\end{array}$ & Treatment & 0.0018 & 1 & 4 & 1.81 & 0.250 \\
& Time & 0.0128 & 1 & 17 & 13.20 & 0.002 \\
\hline C:N ratio & Treatment & 0.0141 & 1 & 4 & 1.005 & 0.373 \\
& Time & 0.1649 & 1 & 17 & 11.691 & 0.003 \\
\hline Cell toxins & Treatment & 41.14 & 1 & 4 & 118.24 & $<0.001$ \\
\hline Log cell nitrogen & Treatment & 0.079 & 1 & 4 & 54.66 & 0.002 \\
\hline Log cell carbon* & Treatment & 0.175 & 1 & 21 & 153.22 & $<0.001$ \\
& Time & 0.006 & 1 & 21 & 4.83 & 0.039 \\
\hline Log rejection* & Treatment & 0.506 & 1 & 19 & 29.236 & $<0.001$
\end{tabular}

*: Random effect variances estimated as (close to) zero. 
Appendix 2 Table S4. Type III analysis of variance (ANOVA) on the fixed effects in the linear mixed models used to analyze the effect of the copepodamide treatment in low dose $(0.63 \mathrm{nM})$ chemostat experiments. $P$-values are provided via Satterthwaite's degrees of freedom method. Some variables were log-transformed to homogenize variances. DR: dilution rate.

\begin{tabular}{|c|c|c|c|c|c|c|}
\hline & Fixed effects & Sum Sq. & NumDF & DenDF & $\mathrm{F}$ & $P$ \\
\hline \multirow[t]{5}{*}{ Cell volume } & Treatment & 53547 & 1 & 92 & 0.856 & 0.356 \\
\hline & Time & 380975 & 1 & 75 & 6.117 & 0.016 \\
\hline & DR & 2944857 & 3 & 16 & 15.762 & $<0.001$ \\
\hline & Treatment $\times$ Time & 35618 & 1 & 75 & 0.572 & 0.452 \\
\hline & Treatment $\times D R$ & 2819502 & 3 & 16 & 15.091 & $<0.001$ \\
\hline \multirow[t]{2}{*}{ Cell growth rate* } & Treatment & 0.0021 & 1 & 97 & 0.334 & 0.564 \\
\hline & $\mathrm{DR}$ & 2.6630 & 3 & 97 & 141.219 & $<0.001$ \\
\hline \multirow{2}{*}{$\begin{array}{l}\text { N-specific growth } \\
\text { rate* }\end{array}$} & Treatment & 0.0143 & 1 & 79 & 1.580 & 0.213 \\
\hline & DR & 1.5605 & 3 & 79 & 57.564 & $<0.001$ \\
\hline \multirow[t]{5}{*}{ C:N ratio* } & Treatment & 0.01 & 1 & 80 & 0.016 & 0.899 \\
\hline & Time & 2.91 & 1 & 80 & 8.774 & 0.004 \\
\hline & DR & 912.48 & 3 & 80 & 916.081 & $<0.001$ \\
\hline & Treatment $\times$ Time & 0.36 & 1 & 80 & 1.093 & 0.299 \\
\hline & Treatment $\times$ DR & 2.04 & 3 & 80 & 2.049 & 0.114 \\
\hline \multirow[t]{5}{*}{ Log cell toxins } & Treatment & 3.42 & 1 & 91 & 12.29 & $<0.001$ \\
\hline & Time & 3.76 & 1 & 91 & 13.50 & $<0.001$ \\
\hline & DR & 22.16 & 3 & 91 & 26.55 & $<0.001$ \\
\hline & Treatment $\times$ Time & 0.85 & 1 & 91 & 3.07 & 0.083 \\
\hline & Treatment $\times$ DR & 8.67 & 3 & 91 & 10.38 & $<0.001$ \\
\hline \multirow[t]{5}{*}{ Log cell nitrogen* } & Treatment & 0.0013 & 1 & 80 & 0.26 & 0.612 \\
\hline & Time & 0.0609 & 1 & 80 & 12.11 & $<0.001$ \\
\hline & $\mathrm{DR}$ & 1.4240 & 3 & 80 & 94.48 & $<0.001$ \\
\hline & Treatment $\times$ Time & 0.0053 & 1 & 80 & 1.05 & 0.309 \\
\hline & Treatment $\times \mathrm{DR}$ & 0.0730 & 3 & 80 & 4.84 & 0.004 \\
\hline \multirow[t]{5}{*}{ Log cell carbon* } & Treatment & 0.001 & 1 & 80 & 0.131 & 0.718 \\
\hline & Time & 0.048 & 1 & 80 & 9.755 & 0.002 \\
\hline & DR & 1.006 & 3 & 80 & 68.463 & $<0.001$ \\
\hline & Treatment $\times$ Time & 0.012 & 1 & 80 & 2.507 & 0.117 \\
\hline & Treatment $\times \mathrm{DR}$ & 0.858 & 3 & 80 & 5.841 & 0.001 \\
\hline \multirow[t]{2}{*}{ Log rejection* } & Treatment & 0.50435 & 1 & 57 & 14.720 & $<0.001$ \\
\hline & DR & 1.73364 & 3 & 57 & 16.866 & $<0.001$ \\
\hline
\end{tabular}

\footnotetext{
*: Random effect variances estimated as (close to) zero.
} 
Appendix 2 Table S5. Summary for chemostat experiments. The values are averaged over time and show means \pm standard deviation. DR: dilution rate.

\begin{tabular}{|c|c|c|c|c|c|c|c|c|c|c|c|c|}
\hline$\overline{\mathrm{DR}}$ & Treatment & Dose & Abundance & Cell growth & $\mathrm{N}$ cell mass & $\begin{array}{l}\mathrm{N} \text {-specific } \\
\text { growth }\end{array}$ & Cell volume & Cell N & Cell C & $\mathrm{C}: \mathrm{N}$ ratio & Cell toxin & Rejection \\
\hline $\mathrm{d}^{-1}$ & & & cells $\mathrm{mL}^{-1}$ & $d^{-1}$ & $\mu \mathrm{g} \mathrm{N} \mathrm{mL} L^{-1}$ & $d^{-1}$ & $\mu \mathrm{m}^{-3}$ & pg N cell ${ }^{-1}$ & pg C cell ${ }^{-1}$ & & $\mathrm{fmol} \mathrm{cell}^{-1}$ & \\
\hline 0.05 & Control & Low & $9591 \pm 1450$ & $0.000 \pm 0.004$ & $0.681 \pm 0.061$ & $0.022 \pm 0.038$ & $3399 \pm 126$ & $70.5 \pm 5.25$ & $795 \pm 40$ & $11.16 \pm 0.91$ & $1.28 \pm 0.23$ & $0.16 \pm 0.04$ \\
\hline 0.05 & Induced & Low & $10173 \pm 1816$ & $-0.012 \pm 0.023$ & $0.806 \pm 0.082$ & $0.020 \pm 0.010$ & $3459 \pm 51$ & $79.8 \pm 7.48$ & $956 \pm 47$ & $12.05 \pm 0.76$ & $1.45 \pm 0.69$ & $0.22 \pm 0.11$ \\
\hline 0.10 & Control & Low & $2282 \pm 1022$ & $-0.036 \pm 0.036$ & $0.221 \pm 0.029$ & $0.096 \pm 0.157$ & $3899 \pm 343$ & $147 \pm 43$ & $1644 \pm 448$ & $11.26 \pm 0.29$ & $0.63 \pm 0.14$ & $0.35 \pm 0.08$ \\
\hline 0.10 & Induced & Low & $2187 \pm 904$ & $-0.025 \pm 0.057$ & $0.203 \pm 0.108$ & $0.143 \pm 0.048$ & $3065 \pm 217$ & $131 \pm 44$ & $1518 \pm 524$ & $11.48 \pm 0.49$ & $0.58 \pm 0.08$ & $0.69 \pm 0.06$ \\
\hline 0.20 & Control & Low & $5133 \pm 416$ & $0.191 \pm 0.094$ & $0.608 \pm 0.039$ & $0.190 \pm 0.057$ & $3317 \pm 78$ & $119 \pm 6.9$ & $553 \pm 28$ & $4.65 \pm 0.10$ & $2.29 \pm 2.22$ & $0.28 \pm 0.08$ \\
\hline 0.20 & Induced & Low & $5391 \pm 402$ & $0.232 \pm 0.070$ & $0.691 \pm 0.087$ & $0.208 \pm 0.064$ & $3308 \pm 138$ & $160 \pm 20$ & $789 \pm 79$ & $4.97 \pm 0.41$ & $7.16 \pm 4.18$ & $0.42 \pm 0.11$ \\
\hline 0.20 & Control & High & $3942 \pm 145$ & $0.193 \pm 0.034$ & $0.560 \pm 0.014$ & $0.193 \pm 0.043$ & $4173 \pm 190$ & $142 \pm 7.1$ & $669 \pm 27$ & $4.75 \pm 0.14$ & $3.62 \pm 0.76$ & $0.24 \pm 0.08$ \\
\hline 0.20 & Induced & High & $3738 \pm 163$ & $0.204 \pm 0.043$ & $0.680 \pm 0.036$ & $0.228 \pm 0.030$ & $3800 \pm 160$ & $183 \pm 4.1$ & $903 \pm 17$ & $4.94 \pm 0.13$ & $21.40 \pm 0.90$ & $0.47 \pm 0.08$ \\
\hline 0.40 & Control & Low & $4611 \pm 333$ & $0.359 \pm 0.087$ & $0.726 \pm 0.090$ & $0.323 \pm 0.081$ & $3862 \pm 211$ & $158 \pm 15$ & $635 \pm 49$ & $4.03 \pm 0.15$ & $22.7 \pm 0.34$ & $0.28 \pm 0.06$ \\
\hline 0.04 & Induced & Low & $4390 \pm 289$ & $0.343 \pm 0.012$ & $0.724 \pm 0.074$ & $0.365 \pm 0.121$ & $3753 \pm 119$ & $165 \pm 13$ & $670 \pm 57$ & $4.06 \pm 0.12$ & $4.18 \pm 1.31$ & $0.38 \pm 0.14$ \\
\hline
\end{tabular}


Appendix 2 Table S6. Summary for chemostat experiments, normalized by cell volume to account for differences in size. The values are averaged over time and show \pm standard deviation. DR: dilution rate.

\begin{tabular}{|c|c|c|c|c|c|c|c|}
\hline $\begin{array}{l}\text { DR } \\
\qquad d^{-1}\end{array}$ & Treatment & Dose & $\begin{array}{c}\text { Biovolume } \\
\times 10^{7} \mu \mathrm{m}^{3} \mathrm{~mL}^{-1}\end{array}$ & $\begin{array}{c}\text { Growth } \\
\mathrm{d}^{-1}\end{array}$ & 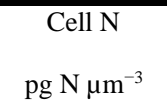 & $\begin{array}{c}\text { Cell C } \\
\operatorname{pg~C~} \mu \mathrm{m}^{-3}\end{array}$ & $\begin{array}{l}\text { Cell toxin } \\
\text { amol } \mu \mathrm{m}^{-3}\end{array}$ \\
\hline 0.05 & Control & Low & $3.269 \pm 0.562$ & $-0.011 \pm 0.024$ & $0.021 \pm 0.002$ & $0.234 \pm 0.016$ & $0.40 \pm 0.06$ \\
\hline 0.05 & Induced & Low & $3.520 \pm 0.658$ & $-0.015 \pm 0.030$ & $0.023 \pm 0.002$ & $0.278 \pm 0.015$ & $0.45 \pm 0.20$ \\
\hline 0.10 & Control & Low & $0.870 \pm 0.340$ & $-0.052 \pm 0.076$ & $0.036 \pm 0.010$ & $0.40 \pm 0.11$ & $0.16 \pm 0.03$ \\
\hline 0.10 & Induced & Low & $0.660 \pm 0.256$ & $-0.066 \pm 0.120$ & $0.042 \pm 0.015$ & $0.48 \pm 0.17$ & $0.19 \pm 0.03$ \\
\hline 0.20 & Control & Low & $1.705 \pm 0.113$ & $0.217 \pm 0.042$ & $0.040 \pm 0.003$ & $0.167 \pm 0.01$ & $0.69 \pm 0.68$ \\
\hline 0.20 & Induced & Low & $1.783 \pm 0.166$ & $0.234 \pm 0.038$ & $0.053 \pm 0.007$ & $0.261 \pm 0.03$ & $2.23 \pm 1.37$ \\
\hline 0.20 & Control & High & $1.644 \pm 0.048$ & $0.208 \pm 0.024$ & $0.034 \pm 0.001$ & $0.160 \pm 0.01$ & $0.88 \pm 0.16$ \\
\hline 0.20 & Induced & High & $1.421 \pm 0.111$ & $0.203 \pm 0.064$ & $0.048 \pm 0.003$ & $0.238 \pm 0.01$ & $5.40 \pm 0.38$ \\
\hline 0.40 & Control & Low & $1.772 \pm 0.066$ & $0.372 \pm 0.043$ & $0.041 \pm 0.005$ & $0.165 \pm 0.01$ & $0.59 \pm 0.09$ \\
\hline 0.40 & Induced & Low & $1.651 \pm 0.141$ & $0.340 \pm 0.053$ & $0.044 \pm 0.004$ & $0.180 \pm 0.02$ & $1.11 \pm 0.35$ \\
\hline
\end{tabular}


Appendix 2 Figure S1.
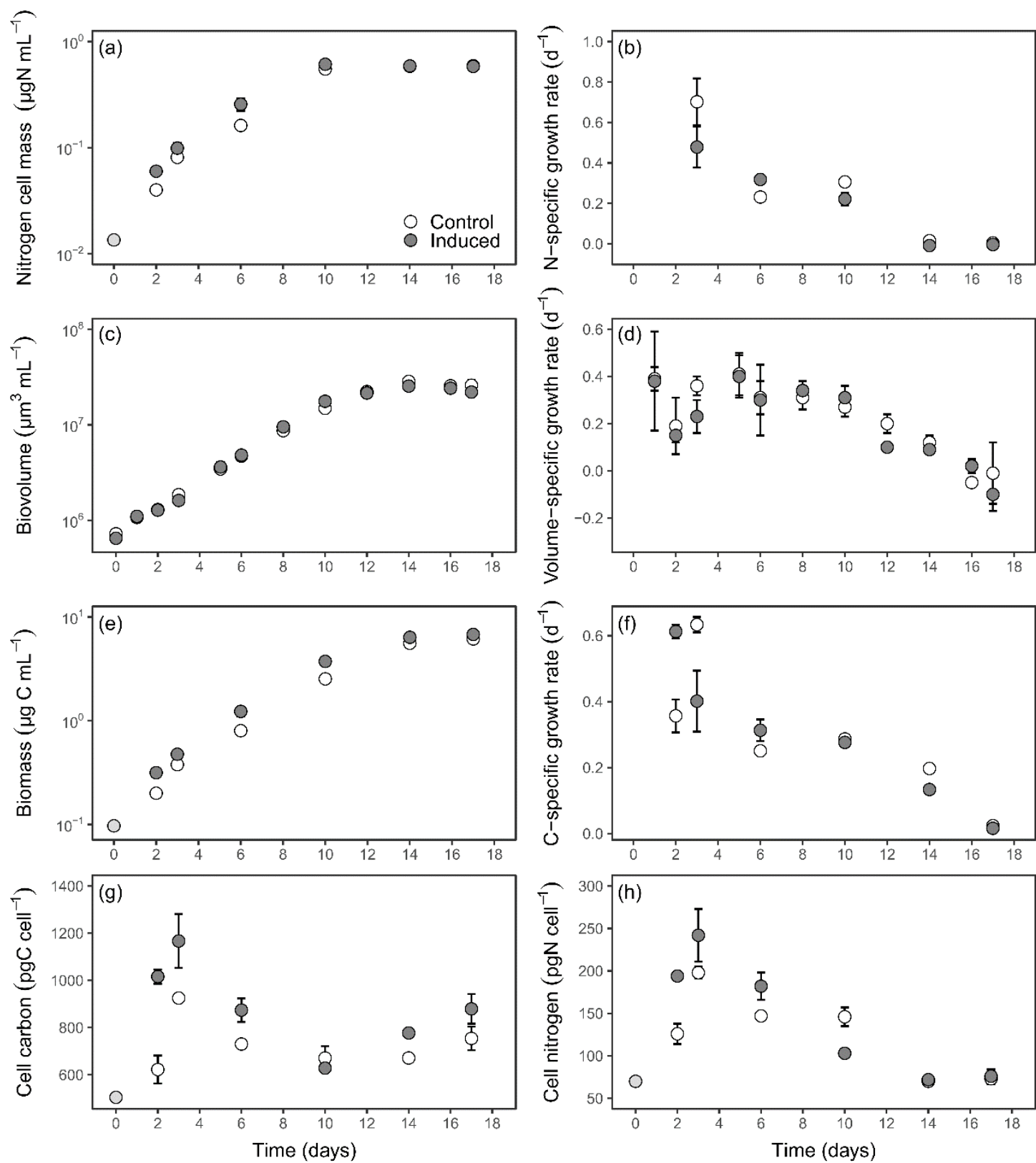

Figure S1. Change in (a) cell-bound nitrogen $\left(\mu \mathrm{g} \mathrm{N} \mathrm{mL}{ }^{-1}\right)$, (b) $\mathrm{N}$-specific growth rate $\left(\mathrm{d}^{-1}\right)$, (c) biovolume $\left(\mu \mathrm{m}^{3} \mathrm{~mL}^{-1}\right),(\mathrm{d})$ volume-specific growth rate $\left(\mathrm{d}^{-1}\right),(\mathrm{e})$ biomass $\left(\mu \mathrm{g} \mathrm{C} \mathrm{mL}^{-1}\right)$, (f) C-specific growth $\left(\mathrm{d}^{-1}\right),(\mathrm{g})$ cellular carbon $\left(\mathrm{pg} \mathrm{C}\right.$ cell $\left.^{-1}\right)$, and (h) cellular nitrogen $(\mathrm{pg} \mathrm{N}$ cell $^{-1}$ ), over time in the batch culture experiment. The grey points in (a), (e), (g) and (h) are initial values taken from the stock culture. Values are means and error bars show standard error $(n=3)$. 
Appendix 2 Figure S2.
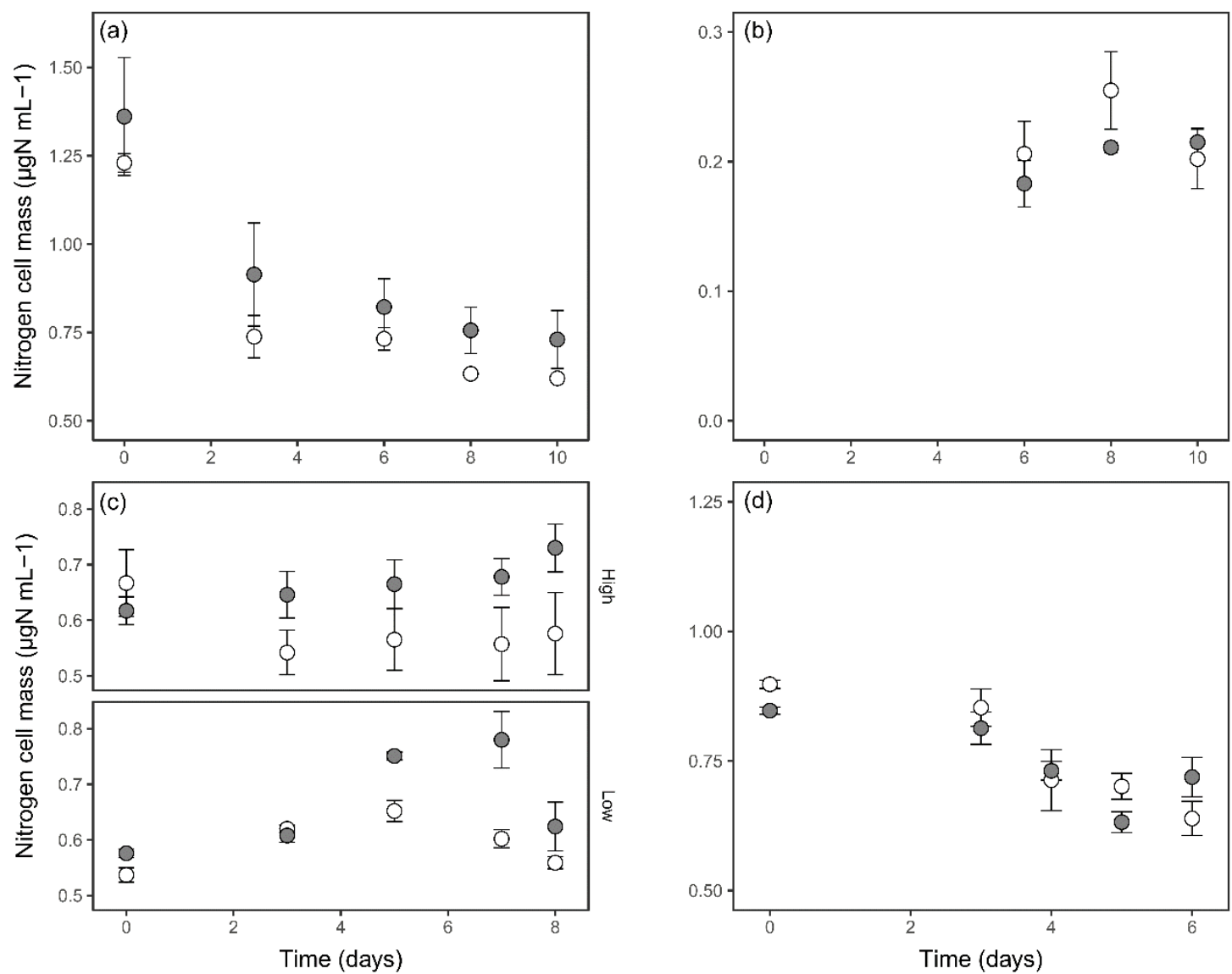

Figure S2. Change in cell-bound nitrogen $\left(\mu \mathrm{g} \mathrm{N} \mathrm{mL}^{-1}\right)$ in the chemostat at the different dilution rates. (a) $0.05 \mathrm{~d}^{-1}$, (b) $0.10 \mathrm{~d}^{-1}$, (c) $0.20 \mathrm{~d}^{-1}$ with high $(6 \mathrm{nM})$ and low $(0.63 \mathrm{nM})$ dose of copepodamides, (d) $0.40 \mathrm{~d}^{-1}$. The values are means and error bars show standard error $(n=3)$. Note the different $y$-axes scales. 
Appendix 2 Figure S3.

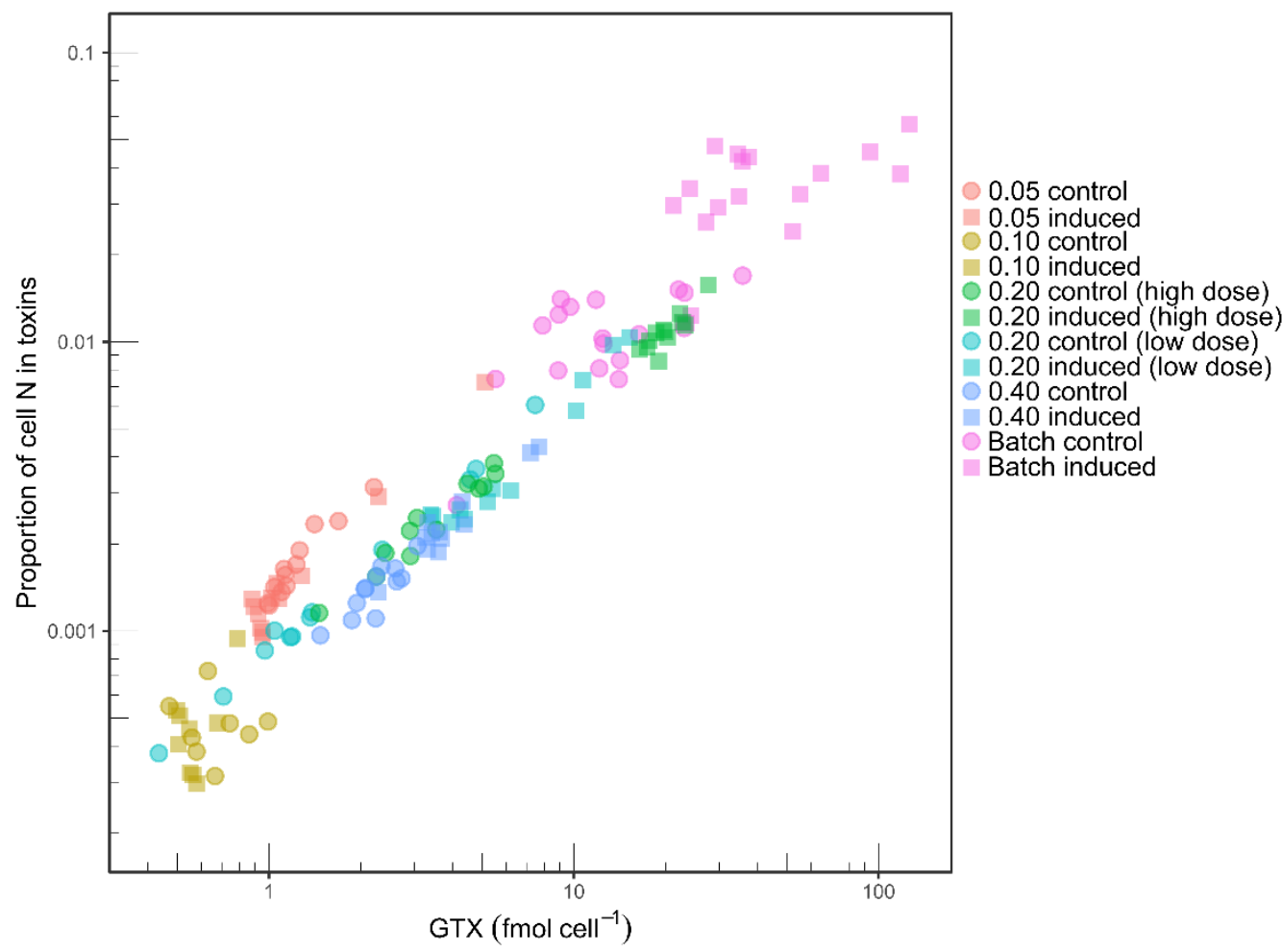

Figure S3. Relation between the proportion of cell nitrogen invested in toxins as a function of the cell toxin content $\left(\mathrm{fmol}\right.$ cell $\left.^{-1}\right)$. 


\section{Supplementary Information}

\section{Appendix 3. Dose-response experiment}

We performed a dose-response experiment to determine toxin-induction potential of different copepodamide concentrations. Triplicate Alexandrium minutum cultures were exposed to four different nominal concentrations $(0,1,5,10 \mathrm{nM})$ of copepodamides under the same conditions as the stock cultures. After 48 hours cells were extracted for toxin analysis as described in the methods section. Cell concentrations were determined using a Beckman Coulter Multisizer 3 (Brea, California, USA).

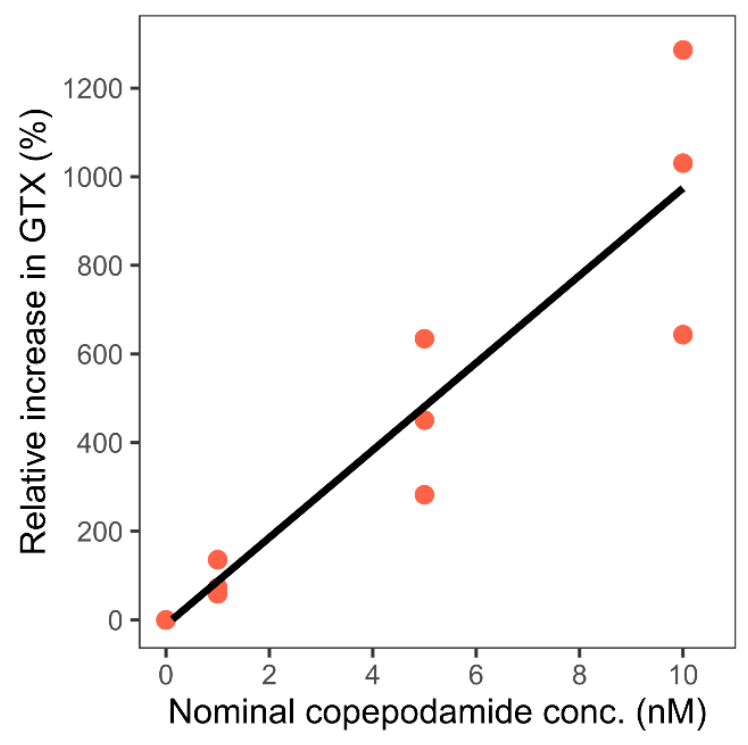

Figure S1. Relation between nominal copepodamide $(\mathrm{Ca})$ concentration $(\mathrm{nM})$ and the increase in cell toxin content relative to the controls in the dose-response experiment. The regression line is $-11.02+98.52 \times \mathrm{Ca}\left(\mathrm{R}^{2}=0.854, p<0.001\right)$. 